\title{
Rhabdomyosarcoma mimicking Wilms' tumor
}

\author{
Department of Pathologyand Oncology of Martagão Gesteira Hospital,Bahiana League \\ against Children's Mortality, Bahia Department of Pathology, of the UNESP' \\ School of Medicine,Botucatu,SãoPaulo.
}

\begin{abstract}
A case of a 6 year old child, with a pleomorphic rhabdomyosarcoma involving simultaneously the leg muscles and the kidney is reported. The renal tumor distorted the pyelocalycial system and Wilms' tumor was the clinical diagnosis.

The authors discuss on the possible primary site of the tumor.
\end{abstract}

UNITERMS: Renal rhabdomyosarcoma, Wilms' tumor, pediatric cancer, renal metastasis.

$\mathbf{R}$ habdomyosarcoma of the kidney is a very rare tumor in adults (4). In children, we found only two reports on this tumor, both with bone metastasis and classified as pleomorphic rhabdomyosarcoma $(3,5)$.

This paper presents a case of pleomorphic rhabdomyosarcoma with immunohistochemical studies occurring simultaneously in the kidney and in muscles of the leg in a child.

\section{CASE REPORT}

A 6 year-old girl, mulatto, had an eight month history of a tumor the right calf that involved exclusively the muscles. The tumor was excised and sent to a hospital for histological study. The diagnosis was rhabdomyosarcoma. After the diagnosis, the patient was hospitalized.

Address for correspondence: Dr. Achiléa Lisboa Bittencourt,

Hospital Martagão Gesteira, Rua José Duarte, 114 -

Tororó - CEP 40.050-050

Salvador, Bahia, Brasil
Examination revealed an enormous and asymmetrical abdomen. A mass was palpable on the right flank. Complete blood count, electrolytes and urinalysis were unremarkable, except for a microcytic anemia. Excretory urography disclosed a tumor in the right kidney with distortion of the pyelocalycial system. Chest and skeletal X-rays did not reveal metastases. A clinical diagnosis of Wilms' tumor stage IV was established. Prior to nephrectomy, the patient was treated with chemotherapy according to a protocol previously described (2) with subsequent reduction of the tumor. After nephrectomy the child was treated with radiotherapy - 2,400 rads in the renal lodge and 4,600 rads in the leg and chemotherapy according to the protocol of the "Société Internationale d'Oncologie Pédiatrique" (6). Seventeen months later the child was reevaluated and was considered disease free.

Pathology 1. Tumor of the right leg. A partially encapsulated, multilobulated tumor weighing $180 \mathrm{~g}$ and measuring $10 \times 8.0 \times 5.0 \mathrm{~cm}$ showed on a section, whitish tissue with necrotic areas. Twelve sections were submitted to microscopical evaluation. Microscopically, the tumor appeared highly cellular. It was mainly composed of cells with indistinct cytoplasm and round hyperchromatic nuclei intermingled with few large cells with vesicular nuclei and abundant and strongly acidophilic cytoplasm, 


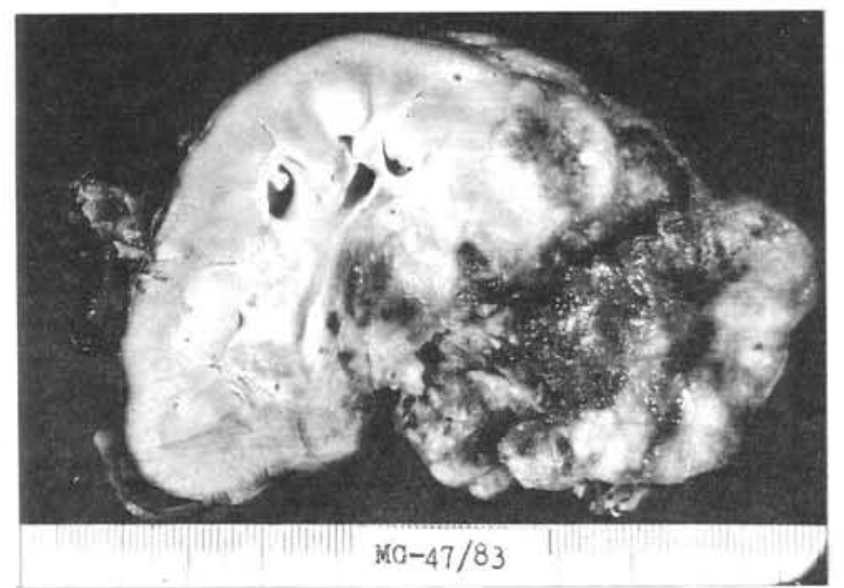

Fig. 1-Kidney tumor, It is not encapsulated and replaces part of the upper pole and the hilus. It shows extensive necrosis and hemorrhage

suggestive of rhabdomyoblasts. In few areas, bundles of spindle cells with a small amount of pale cytoplasm and elongated hyperchromatic nuclei were observed. Extensive areas of necrosis were also seen.

Pathology 2. Kidney tumor. The gross nephrectomy specimen weighed $145 \mathrm{~g}$. The tumor involved part of the upper pole of the kidney and the renal hilus, was not encapsulated and measured $5.5 \times 5.0 \times 5.0 \mathrm{~cm}$. On cut section, the renal parenchyma was replaced by a fleshy gray-whitish tumor with areas of necrosis and hemorrhage (Fig.1).

The ureter and the vessels showed no tumor in the lumen. Microscopically, pleomorphic spindle cells with large hyperchromatic nuclei and with acidophilic cytoplasm were seen (Fig.2). Large polygonal cells with vesicular nuclei and acidophilic cytoplasm were also observed.Areas of fibrosis and old hemorrhage sites were frequently seen.The adrenal was extensively infiltrated.

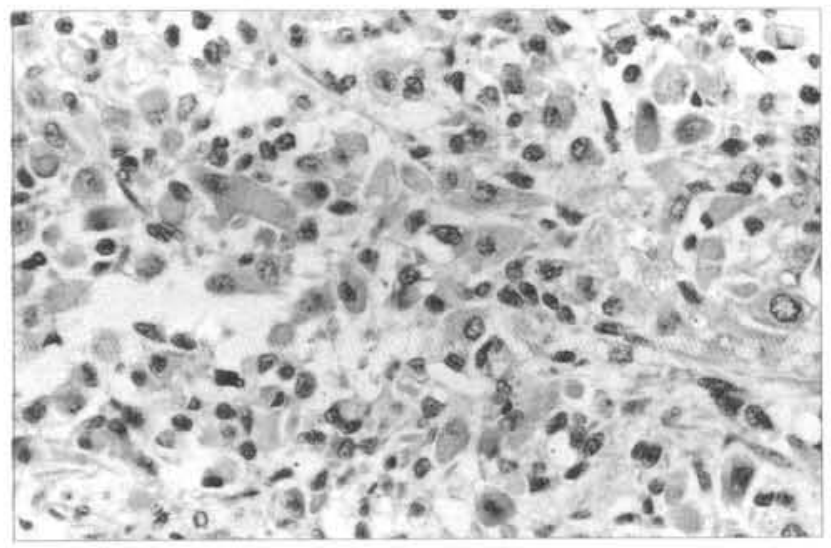

Fig. 2- Renal tumor. See pleomorphic spindle cells with hyperchromatic nuclei and abundant cytoplasm and among them malignant round cells with scarce cytoplasm.

$\mathrm{HE}, \mathrm{X} 320$.

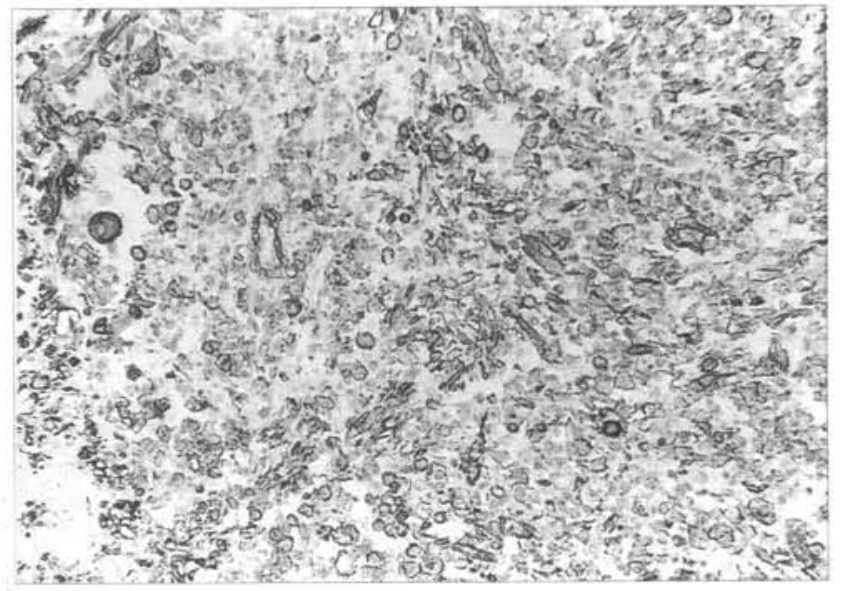

Fig. 3- Renal tumor. Positive immunostaining of the rhabdomyoblastic cells. HHF-35,X 64.

In order to exclude nephroblastoma, the turnor was sampled extensively (a total of 26 sections were examined). Blastema and epithelial structures were not observed. Immunostaining of sections of both tumors revealed positive for muscle specific actin HHF-35 (7) (Fig. 3).

\section{DISCUSSION}

Considering that malignant striated muscle may be a component of Wilms' tumor it could be postulated that children renal rhabdomyosarcoma represents, as a matter of fact, a tumor in which there is an overgrowth of malignant striated muscle (5). However, in the present case, the renal tumor was extensively sampled and no other components were observed, enabling the diagnosis of rhabdomyosarcoma.

Both, muscle and renal tumors represented the pleomorphic variety of rhabdomyosarcoma, but the last tumor was more differentiated. The malignant cells were positive to muscle-specific actin confirming the muscular nature of the lesions. The pleomorphic variety of renalrhabdomyosarcoma has been described in adults although rarely, but the two cases of pediatric renal rhabdomyosarcomas reported in the literature presented with similar histological pattern $(3,5)$.

In the present case, an accurate differential diagnosis between a primary renal tumor and a retroperitoneal metastasis with secondary kidney involvement is difficult to make. However, some aspects led to the assumption that the kidney lesion represents a metastasis. This tumor was not encapsulated and presented with a better cytodifferentiation as it occurs in the metastases of rhabdomyosarcomas. Besides, rhabdomyosarcoma is mainly located in the larger limb muscles (1). 


\section{REFERENCES}

1. AGAMANOLIS, D.P.; DASU, S. \& KRILL, C.E.- Tumors of skeletal muscle. Human Pathol, 17: 778-795, 1986.

2. BITTENCOURT, A.L.; FONSECA JUNIOR, L.E.; MENDONÇA, N.; SAPUCAIA, J.B. \& CORDEIRO, C.O.Tumor de Wilms. Estudo clínico-patológico de 55 casos. J Pediat, 63: 110-114, 1987.

3. GONZALEZ-CRUSSI, F.; HSUCH, W. \& GARTE, N.Rhabdomyogenesis in renal neoplasia of childhood. Am J Surg Pathol, 5: 525-532, 1981.

4. GRIGNON,D.J.; GARY,P.; ARMSTRONG, R.F.\&WYATT, J.K.- Primary rhabdomyosarcoma of the kidney. A light microscopic, immunohistochemical and electron microscopic study. Cancer, 62: 2027-2032, 1988.
5. LIFSCHULTZ, B.D.; GONZALEZ-CRUSSI, F. \& KIDD, J.M.- Renal rhabdomyosarcoma of childhood. J Urol, 127: 309-310, 1982.

6. SIOP.- A therapeutic trial and prospective study. SIOP nephroblastoma clinical trial protocol, 5: 9-13, 1977.

7. TSUKADA, Y.; TIPPENS, D.; MAR, H.; GORDON, D.; ROSS, R. \& GOWN, A.M.- HHF-35, a muscle actin-specific monoclonal antibody: Immunocytochemical and biochemical characterization. Am J Pathol, 127: 51-68, 1987.

\section{ACKNOWLEDGEMENTS}

The authors thank Miss Irany Abreu for her help in preparing this manuscript.

\section{RESUMO}

É apresentado um caso de rabdomiossarcoma pleomórfico em criança de seis anos envolvendo simultaneamente a musculatura da perna direita e o rim homolateral. O tumor renal distorcia o sistema pielocalicial e teve diagnóstico clínico de tumor de Wilms. Os autores discutem acerca do possível sítio primário do tumor. 